\title{
JNPH
}

Volume 5 No. 2 (Desember 2017)

(C) The Author(s) 2017

\section{PENGARUH INTERVENSI BERMAIN TERAPEUTIK TERHADAP PENURUNAN NILAI KECEMASAN HOSPITALISASI ANAK PRASEKOLAH DI RSUP dr. HASAN SADIKIN BANDUNG}

\author{
THE IMPACT OF THERAPUTIC PLAY INTERVENTION TO REDUCE THE \\ HOSPITALIZATION ANXIETY SCORE OF PRESCHOOL \\ IN dr. HASAN SADIKIN BANDUNG HOSPITAL
}

\author{
ELSI RAHMADANI, MEITHA DAMAYANTI, WIWI MARDHIYAH \\ SEKOLAH TINGGI ILMU KESEHATAN DEHASEN BENGKULU \\ DEPARTEMEN KEDOKTERAN ANAK RSUP. dr.HASAN SADIKIN BANDUNG \\ DOSEN FAKULTAS KEPERAWATAN UNIVERSITAS PADJADJARAN \\ Email: elsirahmadani@yahoo.co.id /Hp. 085267708487
}

\begin{abstract}
ABSTRAK
Hospitalisasi menyebabkan kecemasan pada anak prasekolah. Kecemasan ini akan berdampak pada tertundanya prosedur medis dan perkembangan anak selanjutnya. Beberapa intervensi sebelumnya telah dilakukan namun perlu dilakukan inovasi diantaranya dengan bermain terapeutik mewarnai (hospital coloring book). Penelitian ini bertujuan untuk menganalisis pengaruh intervensi bermain terapeutik terhadap penurunan nilai kecemasan hospitalisasi anak prasekolah di RSUP dr. Hasan Sadikin Bandung. Jenis penelitian ini adalah quasi ekperimental dengan pre dan post-testcontrol group. Teknik pengambilan sampel menggunakan consecutive sampling dengan sampel berjumlah 36 reponden umur 3-6 tahun (18 responden kelompok intervensi dan 18 responden kelompok kontrol) yang dirawat di RSUP dr. Hasan Sadikin Bandung. Intervensi yang diberikan berupa bermain terapeutik mewarnai bertema rumah sakit selama 2 hari. Skor kecemasan pre dan post-test diukur menggunakan kuesioner kecemasan hospitalisasi anak prasekolah dengan nilai validitas 0,90 dan reliabilitas 0,89 . Analisa data univariat menggunakan deskriptif frekuensi dan deskriptif statistik, sedangkan analisa bivariat menggunakan Chi-Square, Dependent dan Independent T-Tes. Hasil penelitian menunjukkan bahwa ada pengaruh intervensi bermain terapeutik terhadap nilai kecemasan hospitalisasi anak umur 3-6 tahun di RSUP dr. Hasan Sadikin Bandung pada kelompok intervensi $(p=0,000)$. Bemain terapeutik mewarnai ini dapat menurunkan kecemasan, menstimulasi perkembangan motorik halus, menambah pengetahuan, serta memberi rasa senang pada anak. Peneliti menyimpulkan bahwa ada intervensi bermain terapeutik terhadap nilai kecemasan hospitalisasi anak prasekolah di RSUP dr. Hasan Sadikin Bandung, sehingga diharapkan hasil penelitian ini dapat digunakan perawat dalam menurunkan kecemasan hospitalisasi anak prasekolah.
\end{abstract}

Kata Kunci : bermain terapeutik, hospitalisasi, kecemasan, prasekolah

\begin{abstract}
Hospitalization caused anxiety for preschool children. This anxiety had an impact on delayed medical procedures and could affect for the child's development. Several previous interventions have been done but innovation was needed especially therapeutic coloring play (hospital
\end{abstract}


coloring book). The study aimed to analysis the impact of therapeutic play intervention to the hospitalization anxiety score Preschool in dr. Hasan Sadikin Bandung Hospital. This study method was quasi experimental with pre and post-test control control group. The sampling technique used consecutive sampling method with 36 samples of respondents aged range from 3 to 6 years old child (18 respondents were the intervention group and 18 respondents were the control group) admitted at dr. Hasan Sadikin Bandung Hospital. The intervention that has been given coloring play for 2 days with hospital theme. Pre and post-test anxiety scores were measured using hospitalization anxiety questionnaire with a validity score of 0.90 and a reliability of 0.89 . Univariate data analysis used descriptive frequency and statistical descriptive. Bivariate analysis used Chi-square, Dependent and Independent T-Test. Study result showed that was difference of hospitalization anxiety before and after therapeutic coloring play (hospital coloring book) on the intervention group $(\mathrm{p}=0.000)$. Therapeutic coloring play could reduce anxiety, stimulate fine motor development, increase knowledge, and give a sense of fun in children. The conclusion that the impact of theraputic play intervention to reduce the hospitalization anxiety score preschool. Based on finding, it was recommended for nurse can be use therapeutic coloring play (hospital coloring book) to reduce hospitalization anxiety on preschool.

\section{Keywords: anxiety, hospitalization, preschool, therapeutic play}

\section{PENDAHULUAN}

Hospitalisasi adalah suatu proses karena yang mengharuskan anak untuk tinggal dirumah sakit, menjalani terapi dan perawatan sampai pemulangannya kembali ke rumah (Hockenberry \& Wilson, 2013). Anak bisa di hospitaliasasi karena tes diagnostik, prosedur medis, pembedahan, perawatan, pemberian medikasi dan stabilisasi. The National Centre for Health Statistic memperkirakan bahwa 35 juta anak dibawah usia 15 tahun menjalani hospitalisasi setiap tahun (Salmela, Aronen, \& Salantera, 2011). Survei Kesehatan Nasional (2010) menyebutkan bahwa jumlah anak usia prasekolah di Indonesia sebesar 72\% dari jumlah total penduduk Indonesia, sekitar 35 dari 100 anak prasekolah mengalami hospitalisasi. Berdasarkan data yang diperoleh diruang perawatan kenanga 1 RSUP dr. Hasan Sadikin Bandung, rata-rata jumlah pasien anak prasekolah yang dirawat di ruang Kenanga 1 berjumlah 35 anak perbulan.

Berdasarkan Survei Kesehatan Nasional (2010) menemukan bahwa 60\% anak yang dirawat di rumah sakit menunjukkan adanya kecemasan. Kecemasan hospitalisasi ini timbul pada saat perpisahan dengan orang tua, kecemasan terhadap lingkungan asing, kecemasan dan ketakutan terhadap cidera atau nyeri tindakan invasive seperti pembedahan, pemasangan infus, injeksi dan lain-lain (W. H. C. Li et al., 2016).Kecemasan berdampak pada fisiologis anak yaitu nafas cepat, mual, kelemahan, disritmia, sering berkemih, agrresive, gangguan tidur, kehilangan nafsu makan, menolak makanan (Salmela et al., 2011). Dampak terhadap fisiologis akibat kecemasan juga menyebabkan penekanan sistem imun anak yang berhubungan dengan kelenjar adrenal akan menghasilkan hormon kortisol dalam jumlah yang banyak sebagai akibat kecemasan dan stress sehingga mempercepat terjadinya komplikasi selama perawatan, waktu perawatan lebih lama dan penyembuhan luka lambat (Francischinelli et al., 2012).

Dampak kecemasan terhadap psikologis anak yaitu akan menghambat kemampuan koping anak-anak dalam mengatasi perawatan medis, dan anak akan berperilaku tidak kooperatif terhadap tim kesehatan (W. H. C. Li et al., 2016). Dampak selanjutnya dari kecemasan hospitalisasi adalah tertunda dan membutuhkan waktu yang lama dalam tindakan/prosedur medis (Rosalia, 2016). Keadaan ini membuat waktu yang dibutuhkan untuk merawat anak $20 \%$ - $45 \%$ melebihi waktu untuk merawat orang dewasa (Survei Kesehatan Nasional, 2010). Dampak 
kecemasan hospitalisasi juga akan mempengaruhi perilaku (emosional) anak bahkan sampai anak pulang kerumah (Rennick et al., 2014). Sebanyak 67\% perilaku dan emosi kecemasan anak selama prosedur invasive dapat menetap sampai 6 bulan dan dampaknya berupa perilaku agresive Hong $\mathrm{Gu} \mathrm{He}$ et al (2014).Penelitian Ramdaniati, Hermaningsih \& Muryati (2016) menunjukkan bahwa saat hospitalisasi $43,5 \%$ anak prasekolah mengalami cemas berat, $34,8 \%$ cemas sedang dan $21,7 \%$ cemas ringan.

Anak usia prasekolah adalah anak berusia 3-6 tahun dan termasuk dalam fase kanak-kanak awal (Hockenberry \& Wilson, 2013). Psikoemosional anak pada usia ini masih dalam perkembangan. Berfikir magis dan fantasi adalah perkembangan yang paling dominan sangat pada anak prasekolah (Carman \& Kyle, 2015). Beberapa emosi umum yang berkembang yaitu takut, marah, cemburu, kegembiraan, kasih sayang, phobia, cemas (takut karena khayalan). Anak menganggap sakit merupakan hukuman dari perbuatan yang telah dilakukan (Francischinelli et al., 2012). Kondisi kognitif anak masih berkembang, anak prasekolah memiliki keterbatasan pengetahuan tentang tubuhnya. Ketidakmampuan merasionalisasi sebab dan akibat suatu penyakit atau cidera secara logis akan menyulitkan anak untuk memahami kejadian tersebut (Hockenberry \& Wilson, 2013). Sumber daya anak untuk menghadapi situasi yang menyakitkan akan terbatas, kurangnya pengetahuan tentang penyakit, prosedur, kurangnya kontrol, kurangnya penjelasan yang tepat pada anak tentang penyakit, dan prosedur medis menyebabkan anak prasekolah rentan mengalami kecemasan hospitalisasi. Dukungan dari keluarga dan perawat sangat diperlukan pada anak usia prasekolah terutama saat mereka mengalami kondisi hospitalisasi sangat diperlukan anak (Novianty, L., Suryani\&Sriati, A, 2015). Peran perawat sebagai edukator dan fasilitator sangat diperlukan dalam meminimalkan kecemasan hospitalisasi terhadap anak prasekolah.

Peneliti juga melakukan pengamatan dan wawancara pada orang tua di RSUP dr. Hasan Sadikin, bahwa sebagian besar anak prasekolah yang dirawat menunjukkan perilaku menangis, menolak, menjerit, menolak didekati dan tidak kooperatif terutama saat didekati perawat, serta saat tindakan invasif seperti tindakan pemasangan infus dan pengambilan sampel darah. Penelitian bermain terapetik mewarnai sebelumnya telah ada, namun perlu inovasi dengan yaitu intervensi mewarnai dengan gambar tema Rumah Sakit yang masih belum diketahui sehingga peneliti tertarik untuk mengadakan penelitian tentang pengaruh intervensi bermain terapeutik terhadap penurunan nilai kecemasan hospitalisasi anak prasekolah di RSUP dr. Hasan Sadikin Bandung.

\section{METODE PENELITIAN}

Rancangan penelitian yang akan digunakan adalah Quasi Experimental Design denganpendekatan pretest-posttest control group before after design artinya suatudesain yang melakukan perlakuan pada dua atau lebih kelompok kemudian diobservasi sebelum dan sesudah perlakuan. Penelitian ini adalah penelitian analitik dengan skala pengukuran kecemasan antara dua kelompok berpasangan. Populasi dalam penelitian ini adalah seluruh pasien anak prasekolah yang dirawat diruang perawatan anak Kenanga 1 RSUP dr. Hasan Sadikin Bandung berjumlah rata-rata 35 anak per bulan. Teknik pengambilan sampel jenis consecutive sampling, dengan jumlah sampel 36 anak prasekolah (18 kelompok kontrol dan 18 kelompok intervensi) dengan kriteria inklusi pasien sadar penuh, skala nyeri 0 (nol), Pada saat dirawat didampingi oleh orang tua/keluarga, bersedia menjadi responden, anak bisa/mampu/diperbolehkan posisi duduk sedangkan kriteria eksklusinya adalah pasien usia prasekolah yang mengalami kelemahan dan keterbatasan gerak ektremitas atas, parese, dan cerebral palsy, tidak kooperatif, 
demam tinggi, mengantuk berat, menjalani perawatan intensif /isolasi / bedrest total, memakai oksigen (nasal/sungkup), terpasang infus kanan/tangan dominan.

Tempat penelitian dilakukan di ruang rawat anak yaitu Kenanga 1 RSUP dr. Hasan Sadikin Bandung.Instrument intervensi yang pakai dalam penelitian ini adalah buku mewarnai (hospital coloring book) yang merupakan pengembangan dan modifikasi dari buku mewarnai "Coloring book U.C. Davis Hospital" (Hoogland, 2010). Setiap gambar dalam buku mewarnai dimodifikasi dan disesuaikan dengan budaya Indonesia, bahasa, usia anak, serta dibuat menarik. Alat pengumpulan data kecemasan menggunakan alat ukur kecemasan hospitalisasi anak prasekolah yaitu lembar observasi yang dikembangkan dan dimodifikasi dari Hockenberry \& Wilson (2013), Subardiah (2009), Widianti (2011).

Lembar kuesioner ini berisi reaksi perilaku kecemasan anak sehingga jumlah total pertanyaan adalah 15 pertanyaan. Setiap pertanyaan/item respon perilaku kecemasan anak yang dinilai dengan skala likert yaitu selalu (4), sering (3), kadang-kadang (2), dan tidak pernah (1) untuk pernyataan negatif, sedangkan untuk pernyataan positif nilainya adalah sebaliknya. Nilai kecemasan terendah adalah 15 dan nilai tertinggi adalah 60. Hasil uji validitas dengan uji pearson product moment didapatkan hasil koefisien korelasi terkoreksi setiap item memiliki nilai 0,51 0,90. dan uji reliabilitas kuesioner dengan nilai alpha Cronbach 0,89. Tahap proses penelitian ini yaitu hari ke-1 dilakukan pengukuran sebelum (pre-test), kemudian dilakukan intervensi penelitian bermain terapeutik mewarnai (hospital coloring book) hari-1 dan ke-2 kemudian dilakukan pengukuran kecemasan setelah (post-test) 2 hari selama 30 menit perhari. Analisis data dalam penelitian ini menggunakan dependent $t$ test, independent $t$ test.

\section{HASIL PENELITIAN}

1. Perbedaan rata-rata skor kecemasan hospitalisasi anak prasekolah sebelum (Pre-test) dan sesudah (Post-test) bermain terapeutik mewarnai (Hospital Coloring Book) pada kelompok kontrol dan kelompok intervensi.

Tabel 1 Perbedaan rata-rata skor kecemasan sebelum (pre-test) dan (posttest) pada kelompok kontrol dan kelompok intervensi

\begin{tabular}{cccccc}
\hline Skor & \multicolumn{2}{c}{ Pre-test } & \multicolumn{2}{c}{ Post-test } & $p$ \\
kecemasan & Mean & SD & Mean & SD & \\
\hline $\begin{array}{c}\text { Kelompok } \\
\text { Kontrol }\end{array}$ & 37,61 & 4,80 & 39,61 & 3,87 & 0,002 \\
& & & & & \\
\hline $\begin{array}{c}\text { Kelompok } \\
\text { Intervensi }\end{array}$ & 37,72 & 3,56 & 32,89 & 3,59 & 0,000 \\
\hline
\end{tabular}

Berdasarkan tabel diatas diperoleh hasil bahwa rata-rata kecemasan pre-test kelompok kontrol adalah 37,61 dengan standar deviasi 4,80 dan rata-rata kecemasan post-test adalah 39,61 dengan standar deviasi 3,54. Hasil uji statistik (Dependent $T$ Test) yaitu $p=0,002$ $(p<0,05)$ artinya bahwa ada perbedaan ratarata skor kecemasan hospitalisasi anak prasekolah sebelum (pre-test) dan sesudah (post-test) pada kelompok kontrol.

Rata-rata kecemasan anak sebelum (pretest) kelompok intervensi adalah 37,72 dengan standar deviasi 3,56 dan rata-rata kecemasan setelah (post-test) pada kelompok intervensi adalah 32,89 dengan standar deviasi 3,59 serta $p=0,000(p<0,05)$ artinya bahwa ada perbedaan rata-rata skor kecemasan hospitalisasi anak prasekolah sebelum (pre-test) dan sesudah (post-test) bermain terapeutik mewarnai (hospital coloring book) pada kelompok intervensi.

2. Perbedaan rata-rata skor kecemasan anak sebelum (Pre-test) dan sesudah (Post-Test) pada kelompok kontrol dan kelompok intervensi serta perbedaan rata-rata skor kecemasan anak pada kelompok kontrol dan kelompok intervensi.

$\begin{array}{lccc}\text { Tabel } 2 & \begin{array}{c}\text { Perbedaan } \\ \text { sebelum }\end{array} & \begin{array}{c}\text { rata-rata } \\ \text { (pre-test) }\end{array} & \begin{array}{c}\text { skor } \\ \text { pada }\end{array}\end{array}$


kelompok kontrol dan kelompok intervensi serta perbedaan rata-rata skor kecemasan sesudah (post-test) pada kelompok kontrol dan kelompok intervensi

\begin{tabular}{cccccc}
\hline $\begin{array}{c}\text { Skor } \\
\text { Kecemasa } \\
\mathrm{n}\end{array}$ & \multicolumn{2}{c}{$\begin{array}{c}\text { Kelompok } \\
\text { Kontrol }\end{array}$} & \multicolumn{2}{c}{$\begin{array}{c}\text { Kelompok } \\
\text { Intervensi } \\
\text { Mean } S D\end{array}$} & $p$ \\
\hline Pre-test & 37,61 & 4,80 & 37,72 & 3,56 & 0,938 \\
\hline Post-test & 39,61 & 3,87 & 32,89 & 3,59 & 0,000 \\
\hline
\end{tabular}

Berdasarkan tabel diatas diperoleh hasil bahwa rata-rata kecemasan anak sebelum (pre-test) pada kelompok kontrol adalah 37,61 dengan standar deviasi 4,80 dan ratarata kecemasan sebelum (pre-test) pada kelompok intervensi adalah 37,72 dengan standar deviasi 3,56. Selain itu didapatkan juga hasil uji statistik (Independent Test) yaitu $p=0,938(p>0,05)$ artinya bahwa tidak ada perbedaan rata-rata skor kecemasan hospitalisasi anak prasekolah sebelum (pretest) pada kelompok kontrol dan kelompok intervensi.

Berdasarkan tabel ini juga diketahui bahwa rata-rata kecemasan setelah (post-test) kelompok intervensi adalah 32,89 dengan standar deviasi 3,59 dan rata-rata kecemasan setelah (post-test) pada kelompok kontrol adalah 39,61 dengan standar deviasi 3,87. Hasil uji statistik (Independent Test) yaitu $p=0,000(p<0,05)$ artinya ada perbedaan ratarata skor kecemasan hospitalisasi anak prasekolah setelah (post-test) pada kelompok kontrol dan kelompok intervensi.

3. Perbedaan rata-rata selisih (penurunan) skor kecemasan hospitalisasi anak prasekolah pada kelompok kontrol dan kelompok intervensi.

Tabel 3 Rata-rata selisih (penurunan) skor kecemasan hospitalisasi anak pada kelompok kontrol dan kelompok intervensi

\begin{tabular}{rcc}
\hline Skor Kecemasan Kelompok & Kelompok & $p$ \\
Kontrol & Intervensi & \\
Mean SD & MeanSD & \\
\hline
\end{tabular}

Selisih

\begin{tabular}{llllll} 
(pretest-postest) 2,67 & 1,49 & 4,83 & 1,82 & 0,000 \\
\hline
\end{tabular}

Berdasarkan tabel diatas diperoleh hasil bahwa nilai kecemasan sebelum (pre-test) pada kelompok kontrol adalah 37,61 dan nilai kecemasan setelah (post-test) 39,61 terjadi peningkatan rata-rata nilai (selisih) yaitu 2,67 sedangkan pada kelompok intervensi nilai kecemasan sebelum (pre-test) adalah 37,72 dan kecemasan setelah intervensi (post-test) adalah 32,89 terjadi penurunan rata-rata nilai kecemasan (selisih) yaitu 4,83. Hasil uji statistik (Independent Test) menunjukkan nilai $p=0,000 \quad(p<0,05) \quad$ artinya bahwa ada perbedaan rata-rata selisih (penurunan) skor kecemasan hospitalisasi anak prasekolah pada kelompok kontrol dan kelompok intervensi.

\section{PEMBAHASAN}

Hospitalisasi dapat menimbulkan reaksi kecemasan pada anak prasekolah. Kecemasan ini disebabkan oleh penyakit anak, prosedur medis, prosedur invasive, nyeri anak, lingkungan rumah sakit, tenaga kesehatan, ketidaktahuan dan ancaman fisik serta system diri. Kecemasan hospitalisasi tersebut dipengaruhi oleh beberapa faktor yaitu usia perkembangan, support sistem, pengalaman hospitalisasi, lama rawat dan jenis kelamin. Anak usia prasekolah yang perkembangan kognitif dan emosional masih terbatas, membuat anak pada usia ini memiliki kecemasan yang tinggi saat hospitalisasi.

Bermain terapeutik mewarnai berpotensi memberikan pengaruh positif terhadap kecemasan anak prasekolah yang menjalani hospitalisasi. Hal ini didukung oleh data pada penelitian yang menunjukkan adanya penurunan (selisih) skor kecemasan hospitalisasi anak prasekolah, ada perbedaan skor kecemasan sebelum (pre-test) dan setelah (post-test) bermain terapeutik mewarnai (hospital coloring book) pada kelompok intervensi dan kelompok kontrol yang bermakna dan signifikan secara statistik 
$(\mathrm{p}<0,05)$

Selisih (penurunan) skor kecemasan hospitalisasi setelah bermain terapeutik mewarnai (hospital coloring book) pada penelitian ini, memiliki signifikan yang kuat baik secara numerik. Hal ini dapat terlihat dari nilai rata-rata kecemasan yang mengalami penurunan yang bermakna $(p<0,05)$. Adapun beberapa perubahan perilaku kecemasan yang terjadi pada anak setelah intervensi adalah anak lebih mudah ditidurkan, saat perawat masuk anak hanya kadang-kadang memegangi lengan ibunya, anak tidak mengekpresikan marahnya dengan memukul orang lain, dan anak tetap makan/minum/bermain walaupun perawat mendekatinya.

Hasil penelitian ini didukung oleh penelitian Ramdaniati, Hermaningsih \& Muryati (2016), Beebe et al., (2010) bahwa mewarnai efektif menurunkan kecemasan hospitalisasi anak umur 3-6 tahun, dari ratarata kecemasan berat menjadi kecemasan ringan, bahkan terdapat beberapa anak yang tidak mengalami kecemasan. Penelitian serupa Katale (2007) di Thailand bahwa selain menurunkan kecemasan anak, bermain terapeutik mewarnai tentang rumah sakit juga dapat meningkatkan pengetahuan tentang prosedur operasi dan tujuannya, mengurangi kekawatiran dan ketidaktahuan anak tentang operasi. Anak akan fokus dalam mewarnai gambar sehingga kecemasan dan ketakutan selama anak di hospitalisasi dapat dimimalkan.

Keberhasilan perlakuan pada penelitian ini dipengaruhi oleh beberapa faktor, salah satunya adalah kesesuaian intervensi yang diberikan dengan tahap tumbuh kembang anak prasekolah. Anak pada fase ini tingkat rasa keingintahuan yang tinggi, penasaran, sangat antusias untuk mempelajari hal baru. Hal inilah yang terjadi pada penelitian, dimana anak sangat antusias saat perawat mendekati anak dan memperlihatkan buku mewarnai yang berbeda dari buku mewarnai biasanya. Buku mewarnai yang didesain peneliti dibuat dengan menarik, gambar kartun dengan ekpresi yang lucu serta tema gambar rumah sakit sehingga anak mewarnai gambar tentang perawatan dirumah sakit yang dianggap hal yang baru, maka saat anak mampu melakukannya mereka merasa senang. Anak merasa sensasi pencapaian ketika berhasil mencapai melaksanakan aktivitas dan merasa bangga (Kyle \& Carman, 2015).

Buku mewarnai (hospital coloring book) pada penelitian ini juga didesain sesuai dengan perkembangan motorik halus anak usia prasekolah. Perkembangan motorik halus usia prasekolah berupa kemampuan menulis dan menggambar serta mewarnai gambar secara bebas ini didesain menggunakan dengan resolusi gambar besar yaitu ukuran A3 dan pada halaman terakhir ada gambar botol infus yang disertai kotak untuk menempelkan stiker superhero. Ukuran gambar yang besar ini akan membuat anak bebas mewarnai, serta stiker superhero ini dapat menjadi pendukung keberhasilan pemberian cairan dan obat melalui infus. Hal ini disesuaikan dengan fase perkembangan anak usia prasekolah yang sangat percaya dengan pemikiran magis dan fantasi termasuk peran pahlawan (superhero) yang sangat dominan sehingga emosional kecemasan anak minimal (Kyle \& Carman, 2015). Fantasi dan pemikiran magis mendominasi pemikiran anak prasekolah membuat mereka sulit memahami tentang sebab akibat penyakit sehingga pemberian informasi melalui gambar mewarnai dan penjelasan perawat sangat penting (Hockenberry \& Wilson, 2013).

Usia prasekolah merupakan masa dimana perkembangan motorik halus berkembang pesat, salah satunya anak mulai mampu memegang crayon, pena secara bebas, mulai mengenal warna dan senang mewarnai gambar dengan bebas, sehingga aktivitas bermain mewarnai merupakan hal yang tepat pada anak usia ini (Kliegman, Behrman, \& Stanton, 2011). Berdasarkan pada perkembangan tersebut maka bermain terapeutik mewarnai (hospital coloring book) sesuai untuk perkembangan anak prasekolah. Perawat menjelaskan tentang gambar pada buku mewarnai dan menanyakan warna apa 
yang diinginkan anak untuk digunakan sehingga manfaat anak dapat mengenal warna dapat terpenuhi.

Hasil yang ditemukan dalam penelitian ini bahwa anak prasekolah dapat mengenal minimal 4 warna yaitu, kuning, merah, biru dan hitam. Hal ini disesuaikan pada usia prasekolah bahwa anak mulai mengetahui beberapa warna terutama warna terang (Kyle \& Carman, 2015). Melalui mewarnai gambar, seorang dapat menuangkan simbolisasi tekanan atau kondisi traumatis yang dialaminya kedalam coretan dan pemilihan warna. Dinamika secara psikologis menggambarkan bahwa individu dapat menyalurkan perasaan - perasaan yang tersimpan dalam bawah sadarnya dan tidak dapat dimunculkan kedalam realita melalui gambar. Saat mewarnai gambar, seseorang secara tidak sadar telah mengeluarkan muatan amigdalanya, yaitu mengekspresikan rasa sedih, tertekan, stres.

Warna juga dapat memberi daya tarik bagi anak, pembentuk sifat karakter, pembuat suasana dan pembangkit emosi, serta warna dapat memunculkan imajinasi pada anak (John et al., 2012). Warna juga merupakan terapi (Curry \& Kaser, 2005). Terapi warna melalui sebuah spektrum cahaya mampu meningkatkan kadar hormon serotonin yang berfungsi untuk mengontrol sejumlah perilaku atau perasaan (mood) seseorang dapat menciptakan rasa bahagia dan menurunkan stres atau rasa cemas individu (Wijayanto \& Vera, 2013).

Warna ini memiliki fungsi terhadap kesehatan dan perkembangan anak diantaranya adalah warna kuning dapat menstimulasi kecerdasan anak, pernafasan lebih stabil. Warna merah dapat memberi energik (semangat), peningkatan kemampuan motorik anak, kesenangan. Warna biru memberi ketenangan, menurunkan tekanan darah dan detak jantung, melemaskan otot dan pikiran. Warna pink memberikan kelembutan, menenangkan dan kasih sayang, energik. Di lingkungan pediatrik penggunaan warna yang cerah namun menenangkan, menarik akan memberikan manfaat terutama untuk kesehatan anak. Warna hijau adalah warna yang terkait dengan hijau dapat memberi keseimbangan, harmoni, menghibur dan menghilangkan stress, menenangkan dan merupakan warna alam. Di dalam tubuh, hijau berhubungan dengan jantung, paru-paru, sistem peredaran darah serta menyegarkan (Guido,2011).

Jalur utama dari mekanisme transmisi warna menuju sistem limbik dan sistem endokrin adalah Retinohypothalamic tract yang merupakan salah satu jalur dimana hipotalamus menghubungkan sistem saraf dengan Autonomic Nervous System (ANS) dan sistem endokrin (Honig, 2007). Hal ini semakin diperkuat dengan penelitian yang dilakukan oleh Shealy, dkk dalam Honig (2007) yang menemukan bahwa warna hijau dapat menyebabkan terjadinya peningkatan rata-rata kadar serotonin, oksitosin, beta endorfin dan growth hormone serta dapat juga menyebabkan terjadinya penurunan kadar norepinefrin. Perubahan kadar zat kimia saraf dan neurohormon tersebut memiliki pengaruh ataupun peranan penting dalam menurunkan kecemasan seseorang.

Terapi warna hijau akan merangsang pelepasan serotonin (Psychother, 2005). Serotonin disekresikan oleh nukleus yang berasal dari medial batang otak dan berproyeksi di sebagian besar daerah otak, khususnya yang menuju radiks dorsalis medula spinalis dan hipotalamus. Setelah dilepaskan, serotonin mampu mengaktifkan reseptor serotonin pre-sinaps maupun postsinaps kemudian terjadi peningkatan kadar serotonin dalam tubuh yang akan dapat meningkatkan mood seseorang sehingga dapat menciptakan rasa bahagia dan menurunkan stress. Salah satu peran penting serotonin dalam kondisi normal adalah mengatur status mood dan serotonin merupakan hormon yang menenangkan diri yang dapat membuat seseorang merasa senang.

Adapun hormon lain yang dirangsang oleh hipotalamus adalah oksitosin. Oksitosin dibuat di magnocellular neurosecretory cells di supraoptik dan nukleus paraventrikular. 
Oksitosin dapat menginduksi anti stress dan kecemasan serta memberikan efek dalam penurunan tekanan darah dan kadar kortisol. Tingkat oksitosin berhubungan dengan kecemasan dan stres secara dua arah, yaitu oksitosin memberikan efek ansiolitik (anti kecemasan) dan juga dirilis dalam respon terhadap stres. Pemberian terapi warna hijau dapat meningkatkan kadar oksitosin dalam darah, sehingga efek ansiolitik yang dikeluarkan dapat menurunkan kecemasan (Muharyani., Jaji., \& Sijabat 2015).

Sejalan dengan proses tersebut secara fisiologis, ketika anak mewarnai akan merangsang corticotropin releasing factor (CRF). Substansi tersebut akan menstimulasi hipofisis untuk meningkatkan sekresi hormon endorphine dan pro opioid melano cortin (POMC) yang akan meningkatkan produksi ensefalin oleh medula adrenal sehingga mempengaruhi suasan hati menjadi senang dan memberikan perasaan rileks. Dengan meningkatnya endorpin maka terjadi penurunan kerja saraf simpatis, meningkatkan pengaktifan saraf parasimpatis yang bekerja dengan cara menstimulasi medula adrenal untuk menurunkan pengeluaran epinefrin, noreepinefrin, dan kortisol (hormon yang terlibat dalam kecemasan) serta nitric oxide dalam darah, kemudian terjadi penurunan denyut nadi, tekanan darah, konsumsi oksigen, metabolisme tubuh, produksi laktat sehingga seseorang akan merasa nyaman (Park et al., 2013). Perubahan fisik tersebut menyebabkan psikis juga akan merasa tenang dan terjadi pengotrolan perilaku/kecemasan menurun (Yamamoto \& Nagata, 2011).

Bermain terapeutik mewarnai (hospital coloring book) dalam penelitian ini merupakan intervensi bermain menggunakan teknik model sarana gambar kartun tentang lingkungan rumah sakit dan perawatannya. Gambar-gambar dalam buku mewarnai (hospital coloring book) berupa gambar tentang penyebab anak dirawat, perawat dan dokter yang ditemui saat hospitalisasi, tindakan rutin, invasif saat dirawat, alat medis serta penggunaannya. Gambar-gambar ini merupakan gambaran keadaan yang akan terjadi pada anak saat dirawat, sehingga kecemasan dan ketakutan akibat ketidaktahuan dapat diminimalkan. Pemodelan ini didasarkan bahwa kecemasan terjadi akibat ketidaktahuan anak, serta anakanak dapat diajarkan perilaku sesuai dengan kemampuan koping dengan melihat sesuatu yang sama dengan yang akan mereka alami (Katale, 2007). Semakin besar kesamaan antara gambar (model) yang dilihat, dengan kondisi anak maka kecemasan anak akan berkurang.

Gambar yang mirip dengan kondisi anak saat perawatan disertai penjelasan tentang keadaan lingkungan di rumah sakit, proses perawatan, tim kesehatan terutama dokter dan perawat yang paling sering ditemui, membuat anak memiliki pengetahuan tentang manfaat dari hospitalisasi, prosedur serta lingkungan rumah sakit sehingga persepsi anak terhadap perawatannya lebih luas. Konsep diri dan koping anak menjadi positif. Anak merasa lebih nyaman saat dirumah sakit dan percaya terhadap tim medis sehingga anak memiliki kemampuan dalam berinteraksi dengan lingkungan rumah sakit (kooperatif) baik itu dengan tim medis maupun dengan pasien disekitar anak dan tidak terlalu bergantung dengan orang tua. Koping positif ini ditandai dengan perilaku dan emosi yang positif ini yang membuat kecemasan berkurang secara psikologis (Eaton \& Tieber, 2017).

\section{KESIMPULAN}

Berdasarkan hasil penelitian dan pembahasan, simpulan umum dalam penelitian ini adalah terdapat pengaruh intervensi bermain terapeutik terhadap penurunan nilai kecemasan hospitalisasi anak prasekolah di RSUP dr. Hasan Sadikin Bandung.

\section{SARAN}

Hasil penelitian ini dapat menjadi bahan telaah bagi pihak rumah sakit dalam upaya perawatan anak prasekolah yang mengalami kecemasan hospitalisasi, menggunakan 
intervensi bermain terapeutik mewarnai (hospital coloring book). Penelitian ini dapat dijadikan sebagai bahan telaah untuk menambah pondasi keilmuan/kurikulum keperawatan anak tentang kecemasan anak menggunakan bermain mewarnai. Untuk peneliti selanjutnya untuk menggunakan sampel multi setting, serta adanya pengukuran motorik halus anak setelah intervensi menggunakan alat ukur yang sesuai.

\section{DAFTAR PUSTAKA}

American Academy of Pediatrics. (2010). Prevention of Drawning in infant, children, adolescents. Pediatrics, 112 (2), 437. 439.

Aydin, T. (2008). Do not mask the mask: use it. Journal pediatric anesthesia volume 18 , issue 2 february 2008 pages $107-112$ doi: 10.1111/j.1460-9592.2007.02381

Curry, N.A., \& Kasser, T. (2005). Can coloring mandalas reduce anciety? Journal of the American Art Therapy Association, 22(2), 81-85.

Dahlan, S. (2014). Membuat proposal penelitian bidang kedokteran dan kesehatan. Jakarta : Sagung Seto

Donna Koller, P. (2008). Child Life Council Evidence-Based Practice Statement Child Life Assessment: Variables Associated with a Child's Ability to Cope with Hospitalization, (August), 1-16. Retrieved from https://www.childlife.org/files/EBPAsses smentStatement-Complete.pdf

Eaton, J.,\& Tieber, C. (2017). The Effects of Coloring on Anxiety, Mood, and

Fincher, W., Shaw, J., \& Ramelet, A. S. (2012). The effectiveness of a standardised preoperative preparation in reducing child and parent anxiety: A single-blind randomised controlled trial. Journal of Clinical Nursing, 21(7-8), 946-955. https://doi.org/10.1111/j.13652702.2011.03973.x

Francischinelli, A. G. ., Almeida, F. A. \&, \& Fernandes, M. S. . (2012). Routine use of therapeutic play in the care of hospitalized children: nurses' perceptions. Acta Paul Enferm, 25(1), 18-23. https://doi.org/10.1590/S010321002012000100004

Garcia, S. (2014). The effects of education on anxiety levels in patients receiving chemotherapy for the first time: an integrative review. Clinical Journal of Oncology Nursing, 18(5), 516-521. https://doi.org/10.1188/14.cjon.18-05ap

Ghabeli, F., Moheb, N., \& Hosseini Nasab, S. D. (2014). Effect of Toys and Preoperative Visit on Reducing Children's Anxiety and their Parents before Surgery and Satisfaction with the Treatment Process. Journal of Caring Sciences, 3(1), 21-8. https://doi.org/10.5681/jcs.2014.003

He, H. G., Zhu, L., Li, H. C., Wang, W., Vehvilainen-Julkunen, K., \& Chan, S. W. (2014). A randomized controlled trial of the effectiveness of a therapeutic play intervention on outcomes of children undergoing inpatient elective surgery: study protocol. Journal of Advanced Nursing.

https://doi.org/10.1111/jan.12234.

Hockenberry , J. M., \& Wilson, D. (2013). Wong's Essentiala of pediatric Nursingninth Edition. St. Lois Missouri : Elsevier.

Hoogland, C \& Janelle, W. 2010. The Coloring and activity book UC. Davis Hospital. Sacramento.

Kazemi, S., Kazemi, S., Ghazimoghaddam, K,. Besharat, S., Kashani, L. (2012). Music and Anxiety in Hospitalized Children. Iran : Journal of clinical Diagnosis Research.

Kelsey, A., \& Megan, S. (2016). Stress and Coping Related to Medical Illness: Implications for Child Development Item type Electronic Thesis; text. Retrieved from http://hdl.handle.net/10150/144551

Katale, D. (2007). An Intervention To Reduce Anxiety/Fear In Hospitalized Thai School Age Children. United States : Faculty of the Graduate School of the State University of New York. 
Disertation.

Koukourikos, K., Tzeha, L., Pantelidou, P., \& Tsaloglidou, A. (2015). The Importance of Play During Hospitalization of Children. Materia Socio Medica, 27(6), 438.

https://doi.org/10.5455/msm.2015.27.438 $-441$

Kyle, T \& Carman, S. (2015). Buku Ajar keperawatan pediatri Edisi 1. Jakarta : Wolters Klowers EGC.

Li, H. C. W., \& Lopez, V. (2008). Effectiveness and appropriateness of therapeutic play intervention in preparing children for surgery: A randomized controlled trial study. Journal for Specialists in Pediatric Nursing, 13(2), 63-73. https://doi.org/10.1111/j.17446155.2008.00138.x

Li, W. H. C., Oi, J., Chung, K., Ho, K. Y., Ming, B., \& Kwok, C. (2016). Play interventions to reduce anxiety and negative emotions in hospitalized children. BMC Pediatrics, 16(36), 1-9. https://doi.org/10.1186/s12887-0160570-5

Nilsson, S., Buchholz, M., \& Thunberg, G. (2012). Assessing Children's Anxiety Using the Modified Short State-Trait Anxiety Inventory and Talking Mats: A Pilot Study. Nursing Research and Practice, 2012, 1-7. https://doi.org/10.1155/2012/932570

Patimah, I., Suryani., \& Nuraeni, A.(2015). Pengaruh Relaksasi Dzikir terhadap Tingkat Kecemasan Pasien Gagal Ginjal. Jurnal Keperawatan Padjadjaran Volume 3 Nomor 1

Pelander, T., \& H. Leino-Kilpi. (2010). Empirical Studies; Children's best and worst experiences during hospitalization. Finland ScandJournal Caring Science

Perseverance. Journal of the American Art Therapy Association DOI: 10.1080/07421656.2016.1277113

Ramdaniati, S., \& Hermaningsih, S. (2016). Comparison Study of Art Therapy and Play Therapy in Reducing Anxiety on Pre-School Children Who Experience
Hospitalization, (January), 46-52.

Salmela, M., Aronen, E. T., \& Salanterä, S. (2011). The experience of hospitalrelated fears of 4- to 6-year-old children. Child: Care, Health and Development, 37(5), 719-726. https://doi.org/10.1111/j.13652214.2010.01171.x

Survey Kesehatan Nasional. (2010). Jumlah Anak Usia Prasekolah di Indonesia. diakses dari http: // www. rand.org/bps/susenas.html pada tanggal 17 novemver,2016)

Stuart, G.W., \& Laraia, M.T. (2005). Principles and practice of psychiatric nursing (7th ed). St. Louis: Mosby Year.

Vaezzadeh, N., Douki, Z. E., Hadipour, A., Osia, S., Shahmohammadi, S., \& Sadeghi, R. (2011). The Effect of Performing Preoperative Preparation Program on School Age Children's Anxiety. Iranian Journal of Pediatrics, 21(4), 461-6. Retrieved from http://www.pubmedcentral.nih.gov/articl erender.fcgi?

artid $=3446145 \&$ tool $=$ pmcentrez\&rendert ype $=$ abstract

Vagnoli, L., Caprilli, S., \& Messeri, A. (2010). Parental presence, clowns or sedative premedication to treat preoperative anxiety in children: What could be the most promising option? Paediatric Anaesthesia, 20(10), 937943. $\quad$ https://doi.org/10.1111/j.14609592.2010.03403.x

Widianti, C. 2011. Pengaruh Senam Otak Terhadap Kecemasan Akibat Hospitalisasi Pada Anak Usia Prasekolah Di Rumah Sakit Panti Rapih Yogyakarta. Tesis Universitas Indonesia.

Yamamoto,K \& Nagata, S. 2011. Physiological and psychological evaluation of the wrapped warm footbath as a complementary nursing therapy to induce relaxation in hospitalized patients with incurable cancer: a pilot study. Cancer Nurs. 2011 May-Jun;34(3):18592. doi: 10.1097/NCC.0b013e3181fe4d2d. 